\section{Ethical Lingua}

Journal of Language Teaching and Literature

ISSN 2355-3448 (Print)

ISSN 2540-9190 (Online)

Volume 5, Number 2, August 2018

pp. $212-218$

\title{
The Reflection of Regency Gentleman in Pride and Prejudice and Emma by Jane Austen
}

\author{
Andi Febriana Tamrin \\ andifebriana90@unifa.ac.id \\ Universitas Fajar, Indonesia \\ Received : 5 June 2018; Accepted: 3 September 2018 \\ URL : : http://journal.uncp.ac.id/index.php/ethicallingua/article/view/1033 \\ DOI : $\quad$ https://doi.org/10.30605/ethicallingua.v5i2.1033
}

\begin{abstract}
This study is aimed to present the nature of gentleman in the Regency era as reflected in the selected novels of Jane Austen, entitled Pride and Prejudice and Emma. The men who are categorized as gentleman are shifted over the years. In the time before Industrial Revolution, the term "gentleman" belongs to nobility class, gentry or to men who did not use their own hands to work. However, after the Victorian era, the "gentleman" covers several terms. These are the army, clergy, and even for the merchants. The social class and wealth are the prominent factors that cause the changing of this pattern. Nevertheless, Austen's concept of gentleman in her two novels is referred mostly by the virtue and behavior.
\end{abstract}

Keywords: Jane Austen; gentleman; Pride and Prejudice; Emma 


\section{Introduction}

The period when Jane Austen lived her life is known as Georgian period, it was King George who sat on the throne at that time. It has also become the background of her novels in which her characters are set. This era has presented the importance of society, in which case the notorious one is social class.

Jane Austen was belonging to the middle class. She spent all her life among them and endowed with the ability to observe and describing people in their manners, behaviors, and feelings in a very realistic way. Her novels then always deal with varied subjects such as social hierarchies, women and marriage, and the role of society. To support the realistic way of her novels, she created realistic characters, in this case, the heroes and heroines.

Elizabeth Bennet, Anne Elliot, and Emma Woodhouse are some of her famous heroines. At that time, there was a specific term to address them. They could be called lady or miss, which specifically used for women. Meanwhile, for men, there was also a special term for them; it was gentleman or Mr. However. In the most amazing way, Austen presented the heroes in her works compared to heroines. She described them in genteel, funny, and even as a fool.

Jeffers (2017) in her blog presents a statement from Sir Thomas Smith who wrote in 1583: "One who can live idly and without manual labor and will bear the port (department) and countenance of a gentleman, he shall be taken for a gentleman." But then, what someone needs to possess to regard as a gentleman? Cornick (2015) states that the foremost definition of a gentleman is taken from the original dictionary were narrowly defined as a well-educated man of good family. This definition also was applied to a men whose income from their property, which means they did not perform manual works. However, this term got an addition that gentleman also means a man who has a high standard of behavior including a good education, cultured and courteous towards women.

When it comes to Austen's time when the word gentleman is used to define the personal qualities of them as well as their status as a member of the landed gentry. Gentry is a term used to show the position or class of the man in society. It is however different from the peers. The gentry is always related to the belonging of land, hence, the landed gentry.

The meaning of gentility had shifted from the original one. The original one distinguished it from the birthright system to the values and manners of the gentleman. By the time of Industrial Revolution, the new meaning of gentlemen had born. The rising of the middle class had become the roots of spirit for men to reform themselves to be a gentleman by virtue of using their wealth. They could gain their place as gentlemen in upper-class society through intermarriage and purchasing land as much as they could without inherit it. To pursue their desire to 
be the real gentlemen they also equipped themselves by behaving the same way as the "peers" gentlemen. They purchased a new-stylish residence, refined clothes and domestic assets. Therefore, in the past, the gentleman was defined by looking at their wealth, refinement, intelligence and social control that belong to them at the same time without mentioning the implications of their class.

(Sadeq, 2017) presented the idea of a gentleman in one of Austen's work, he concludes that the social classes is one of the reasons why the man regarded as a gentleman and their attempts to even climber to higher class to get the status as the gentleman. In (Tamrin, 2017), she also conducted the same analysis about the nature of Jane Austen's man characters. Her result of study shows that Austen's characters are tended to be a gentleman.

This study is theoretical and analytical. It based on previous studies that carried out concerning the representation of the gentleman in Austen's novels, Pride and Prejudice and Emma. The aim of the study is to see the reflection of the gentleman in the novels and how Austen portrays them.

\section{Method}

This study is qualitative research method. Aminuddin (1990:16) states that the qualitative descriptive method is used to analyze the form of description, not a number of coefficients of the relationship between variables. The selected texts were taken from Austen's novels, Pride and Prejudice and Emma. Documentation and note taking are used to analyze the data.

\section{Results \& Discussion}

Pride and Prejudice and Emma, both of these novels have male characters that fit to describe as a gentleman. What then a gentleman? Several historians, researchers and even sociologists have recently pointed out of the various definitions and interpretations of gentleman concepts. The changing of the periods, conventions in society, classes systems are factors that considerably make it hard to precise the meaning of gentleman. The following are the traits and natures of the gentleman that are put as data and explanations from the selected novels.

\section{The Gentleman in Pride and Prejudice}

The general concept of gentleman in 19th century English is a complex matter to define. As mentioned previously, the gentleman could see from their birth, status and education.

Mr. Darcy is an interesting character from Pride and Prejudice that used in this research to represent the images of the gentleman in Regency period. He is by far is the most notable characters of all Austen's heroes. He has the right 
model to be a gentleman for decades. His actions are proven to be overbearing and his intentions are sometimes too gallant for the other people.

Darcy is the star and has the quality of star that firstly created by Austen. He is portrayed as a quick-witted gentleman and he is in harmony with his heroine. Austen is succeeding to make him as an example of what the gentlemen should be and how they supposedly behave. As the result, currently, he is the epitome of masculinity among the readers.

He is complex character by nature. The way he is portrayed is in tune as for how Cody explain, "the concept of the nineteenth-century gentleman is very complex..." (Cody, 2004). Therefore, Darcy's first appearance in Pride and Prejudice is presented as arrogant and pompous. This makes the society at Meryton reluctant to accept him. "Till his manners gave a disgust which turned the tide of his popularity; for he was discovered to be proud, to be above his company and above being pleased" (PP, 8). In addition, the gentleman of Regency period is the predecessor of the future Victorian gentleman. Therefore, a code of conduct is established based on three Rs: Restraint, Refinement and Religion. At the time of George III sitting on Britain's throne, the British begin to behave in reserving their emotion. This is a way to make them different from another European. As the result, it is the beginning where the gentleman is known for his manners rather that his breeding and fortune (Cornick, 2015).

One of the features that gentleman should be possessed is physical beauty. This feature makes him admirable and desirable to his surroundings, including the ladies. Davis states, "Usually beauty is a sign that such characters are admirable, worthy of imitation and cultural paragons. The physical beauty is a sign of their social status" (1987:123). Mr. Darcy's physical feature succeeds to interest Meryton's society in the ball, "Mr. Darcy soon drew the attention of the room by his fine, tall person, handsome features, noble mien" (PP, 8). It is proven that gentleman is in a need certain feature, namely beauty. Mr. Darcy as portrayed by Austen becomes the new icon of gentleman masculinity. His beautiful features are desirable in the eyes of a female, especially the heroine, Elizabeth.

However, this physical beauty is in contrast to his manner. As mentioned before, the gentleman is known for his manners. Yet, Darcy "was discovered to be proud; to be above his company and above being pleased" (PP, 8). This illustration of him is by far of the gentleman should behave. He behaves as everyone below him. Nobody is able to match him, as a wealthy landowner and as a man from the city. This attitude of him, however, is one of the real expressions of how the usual gentleman behaves in Regency period. Sometimes, the gentleman needs to show who they are and where they come from.

In addition to a gentleman trait before, Mr. Darcy action as a gentleman is described from his dutiful attitude to his sister and housekeeper in Pemberley. 
Due to his atrocious manner, the female character mistook his character. But after a short visit to his estate, Pemberley, his true natures are revealed. He is very dutiful toward his sister, Georgina. Also, the housekeeper singing praises of him:

With praise is more valuable than the praise of intelligent servant? As a brother, a landlord, a master she considered how many people's happiness were in his guardianship!-how much of pleasure or pain was it in his power to besrow!-how much of good or evil must be done by him! Every idea that had been brought forward by the housekeeper was favourable to his character. (pp, 238)

Additionally, his help towards another member of society even though he has no duty to help her. He helps Elizabeth's sister, Lydia, who eloped with Wickham. He provides her with enough dowries for marriage. His action is in fact without the knowledge of anyone, including the sister, Elizabeth. Indeed this action is a proof that he is very much gentleman.

\section{The Gentleman in Emma}

First published in 1815, Emma is no different from Jane Austen in other novels. It depicts the life of a gentleman in Regency era. There are two remarkable male characters in this novel, Mr. Knightley and Mr. Churchil. However, this article discusses only about Mr Knightly and his gentlemanliness.

Warren (1995), states that Knightly was the ideal English man. His integrity, sense of responsibility and tradition, his respect for the social code, his propriety and amiability made him a leading citizen of Highbury. This was where he belonged; it was not where Churchill belonged". It seems that Austen is succeeded in portraying the images of English gentleman in Mr. Knightley.

Compared to Mr. Darcy in Pride and Prejudice, the existence of Mr. Knightley as a gentleman in Emma is way more ideal and modern. His masculinity is a symbol of how he is able to restrain his manners (rudeness) and dominance over Highbury society. Tosh (2005), "masculinity should not be subject to prescription. It should ideally express individual choice". According to this statement, this is how exactly Mr Knightly doing. He is not overconfident and polite. When Emma insults Miss Bates, Mr. Knightley quickly set her right. He said, "How could you so unfeeling to Miss Bates? How could you be so insolent in your wit to a woman of her character, age, and station?" (E, 190). Also, Mr. Knightly is respectful and considerate towards Highbury society. He treats people politely and respectfully.

Mr. Knightley, a sensible man about seven or eight-and-thirty, was not only a very old and intimate friend of the family but particularly connected with it, as the elder brother of Isabella's husband. Mr. Knightley had a cheerful manner, which always did him good; and his many inquiries after "Isabella" and her children were answered most satisfactorily." $(E, 4)$ 
Indeed he has a better manner compared to Darcy. He is the epitome of Austen's hero of Englishman. He always puts manner and behavior first and foremost. Therefore, when he saw Emma made a huge mistake towards Miss Bates, he bravely scolds her of her mistake. He even becomes the role model for Emma when she decides to change.

Mr. Knightly as a true gentleman shows his gentlemanliness through his caring towards his society. He is very helpful and easy to talk to. He tells Emma, "There is one thing, Emma, which a man can always do if he chooses, and that is, his duty: not by maneuvering and finessing, but by vigor and resolution" $(E, 95)$. $\mathrm{He}$ is a very dutiful society. He pays attention towards the smallest thing surround him. He even reminds Emma not to play matchmaker towards Harriet and Mr. Elton, because he believes that her effort will end in vain.

His behaviors are acknowledged by Emma, she said to Mrs. Weston, "I know no man more likely than Mr. Knightley to do the sort of thing - to do anything really good-natured, useful, considerate, or benevolent. He is not a gallant man, but he is a very humane one; and this, considering Jane Fairfax's ill health, would appear a case of humanity to him" $(E, 145)$. His consideration is not ending there, he also feels dutiful to his yeoman, Mr. Martin. He thought well of him and treated him as a gentleman. In addition, even though he thinks highly of Emma, he does not hesitate to reprimand her. Because this attitude of him, Emma admiration can be seen through this statement, "Mr. Knightley's air is so remarkably good that it is not fair to compare Mr. Martin with him. You might not see one in a hundred with a gentleman so plainly written as in Mr. Knightley" (E, 153).

\section{Conclusion}

Based on this study, the researcher would like to represent the image of a gentleman in the Regency through Jane Austen's selected novels. Along the time to define the meaning of gentleman is quite difficult because of several factors. However, based on the analysis from Pride and Prejudice and Emma, Austen's point of view is holding on to the newer version, which is based on their virtue and behavior.

\section{References}

Cody, D. (2004). The Gentleman. Retrieved May 15, 2018, from victorianweb.org: http://victorianweb.org/history/Gentleman.html

Cornick, N. (2015, Agustus 12). What Makes a Gentleman? Historical Post. Retrieved May 30, 2018, from Historical and Regency Romance UK: http://historicalromanceuk.blogspot.com/2015/08/what-makes-gentleman-historic al-post.html

Davis, J. L. (1987). Resisting Novels: Ideology and Fiction. New York and London: Methuen. 
Tamrin:

The Reflection of Regency Gentleman in Pride and Prejudice and Emma by Jane Austen

Grace, M. (2013, September 22). Gentleman, Gentry and Regency Era Social Class.

Retrieved May 30, 2018, from Random Fascination Bits:

http://randombitsoffascination.com/2013/09/22/gentlemen-gentry-regency-era-so cial-class/

Jeffers, R. (2017, June 12). Being a "Gentleman" in Regency England. Retrieved May 30, 2018, from Every Woman Dreams:

https://reginajeffers.blog/2017/06/12/being-a-gentleman-in-regency-england/

Roberts, W. (1995). Jane Austen and the French Revolution. Cambridge: Cambridge University Press.

Sadeq, A. E. (2017). The Presentation of the Gentleman in Jane Austen's Novel Emma (1816). Asian Social Science. https://doi.org/10.5539/ass.v13n7p181

Tamrin, A. F. (2017). Critical Analysis on the Men's Nature in Jane Austen's Emma. Proceedings ICONSS 2017.

Tosh, J. (2005). Manliness and Masculinities in Nineteenth-Century Britain: Essays on Gender, Family and Empire. Harlow: Pearson Longman. 